\title{
Interpretation of Judges in Supreme Court Decision Number: 46 P/HUM/2018
}

\author{
Muslim Andi Yusuf; Dharma Fidyansari
}

\author{
Universitas Cokroaminoto Palopo
}

email: muslimandiyusuf05@gmail.com

\begin{abstract}
This research was conducted to determine the interpretation of judges in the Supreme Court Decision No. 46 P/HUM/2018. This study uses a normative type of research with an approach to identifying legislation and literature that is relevant to research. Data collected from primary, secondary, and tertiary legal materials are analyzed qualitatively, arranged systematically, and presented descriptively. The results of this study indicate that in the Supreme Court Decision Number 46 P/HUM/2018 which judges that Article 4 paragraph (3), Article 11 Paragraph (1) Letter d and Appendix Model B.3 Election Commission Regulation Number 20 of 2018 is contradictory to Law Number 7 of 2017 concerning General Election in conjunction with Law Number 12 of 2011 concerning Formation of Regulations and Judges' Considerations based on the interpretation of the testing object test stones namely the sentences in the text of Law Number 7 of 2017 concerning General Elections and Law Number 12 of 2011 concerning Formation of Legislation as a guide so that the interpretation of judges is based on exploring the meaning contained in the statement written norm text by studying the book in sentence structure or its relationship with other rules.
\end{abstract}

Keywords : Supreme Court Ruling; Judicial Interpretation; Election.

\section{INTRODUCTION}

Election, as one of the instruments of democracy, has an essential function in the process of nation and state, namely the rotation of power. ${ }^{1} \mathrm{~A}$ democratic state change of power is a must that is carried out periodically as an indicator of the quality of democracy, ${ }^{2}$ and Indonesia as a democratic country entrusted with the General Elections in The 1945 Constitution of the Republic of Indonesia.

The post-amendment constitution has provided the basis for the administration of the State and an orderly arrangement of communal life. This is reflected in recognition of people's sovereignty, which is carried out according to the Constitution (Article 1 paragraph 2 of the 1945 Constitution) as well as the confirmation that the State of Indonesia is a constitutional state (Article 1 paragraph 3 of the 1945 Constitution). The basic principles of a democratic rule of law are realized in the form of recognition and guarantee of essential human rights in the democratic process, regulation of the mechanism for electing

IJunaidi, Veri. (2010). Pelanggaran Sistematis, Terstruktur dan Masif: Suatu Sebab Pembatalan Kehendak Rakyat dalam Pemilihan Kepala Daerah Tahun 2010. Jurnal Konstitusi, Mahkamah Konstitusi RI, 7(5), p. 46. doi: https://doi.org/10.31078/jk\%25x

${ }^{2}$ Respationo, H. M. Soerya. (2013). Pemilihan Kepala Daerah dalam Demokrasi Electoral. Masalah-Masalah Hukum, Universitas Diponegoro, 42(3), p. 359. doi: https://doi.org/10.14710/mmh.42.3.2013.356-361 
people's representatives, and public positions as a form of people's sovereignty, as well as structuring State institutions based on the principle checks and balances. ${ }^{3}$

The readiness of all parties determines the quality of the implementation of the General Election. ${ }^{4}$ Some essential issues which are always discussed concerning the general election are the problems of the electoral system and mechanism, political parties and election participants, election organizers as well as the disputed court of election results. ${ }^{5}$ The principle of popular sovereignty is realized through general elections to create political representation in political institutions; the people can determine their participation as voters and run for parliamentary elections and national leaders who will fight for the welfare of the people.

Because of Article 22 E paragraph (1) and paragraph (5) of the 1945 Constitution of the Republic of Indonesia related to the mandate of the General Elections in the Constitution held under Law Number 7 of 2017 concerning General Elections. The Election Commission has the duties, authorities, and obligations stipulated in Article 12, Article 13 and 14 of Law Number 7 of 2017. Among these tasks is to determine election participants following Article 13 paragraph (3) of Law Number 7 of 2017. In carrying out their duties, authorities, and obligations, the General Election Commission is demanded to become an EMB quality as an instrument of realizing people's sovereignty in the electoral procession so that the implementation of people's political rights to vote or be elected directly can be held in a democratic atmosphere.

The elections in 2019 took place in contrast to the previous elections, which were held separately between the DPR, DPD, DPRD, and presidential elections. Elections in April 2019 were held simultaneously in the election of legislative and presidential candidates by the decision of the Constitutional Court of the Republic of Indonesia Number 14/PUU-XI/2013.

Towards the electoral stage, the General Election Commission establishes a policy in the Election Commission Regulation Number 20 of 2018 which prohibits ex-convicts of corruption cases from advancing as legislative candidates, in the third part concerning the requirements for prospective candidates for paragraph 7 letter $h$ ie if those who are allowed to nominate as parliamentary candidates are not former convicted drug dealer, child sex offender, and corruptor.

Election Commission Regulation Number 20 the Year 2018 which prohibits excorruption convicts from advancing as legislative candidates to become Controversial, ${ }^{6}$ Because 377

${ }^{3}$ Asshiddiqie, Jimly. (2009). Menuju Negara Hukum yang Demokratis. Jakarta: PT. Bhuana IImu Populer, p.

${ }^{4}$ Mamonto, Moch. Andry Wikra Wardhana. (2019). Legal Politics of Simplifying Political Parties in Indonesia (Case Study of 2004 - 2014 Election). Substantive Justice International Journal of Law, Universitas Muslim Indonesia, 2(1), p. 4. doi: http://dx.doi.org/10.33096/substantivejustice.v2i1.25

${ }^{5}$ Asshiddiqie, Jimly. (2009). Op. Cit., p. 379.

${ }^{6}$ Hadi, Syafiul, \& Wijanarko, Tulus. (2019, 29 Januari). Hari Ini, KPU Umumkan Caleg yang Mantan Narapidana. Tempo.Co. Retrieved from https://pemilu.tempo.co/read/1169965/hari-ini-kpu-umumkan-caleg-yang-mantannarapidana 
in Article 240 paragraph (1) and (2) of Law Number 7 of 2017 Concerning Election, candidates for legislative members who have been sentenced to prison must fulfill the requirements in paragraph (1) letter g, which is that they have never been sentenced to jail based on a court decision has obtained permanent legal force for committing a crime that is threatened with imprisonment for 5 (five) years or more, unless openly and honestly telling the public that the person concerned is a former convict. In Article 240 paragraphs (1) and (2) of Law Number 7 of 2017 Regarding Election, there is no prohibition of ex-convicts from participating as legislative candidates. Still, ex-convicts who will join as parliamentary candidates must be open and honest in telling the public that concerned is a former convict. Judging from the legislation hierarchy, there is a vertical synchronization between the Election Commission Regulation Number 20 of 2018 and Law Number 7 of 2017 Regarding Elections. The General Election Commission should make regulations referring to higher rules.

The existence of Article 7 letter $h$ of the Election Commission Regulation Number 20 of 2018, which prohibits ex-corruption prisoners from participating as legislative candidates in the 2019 election, makes the ex-convicts of corruption not fulfill the requirements as election participants based on the Election Commission Regulation Number 20 of 2018. This then makes some citizens who feel aggrieved by their political rights submit a material test of the Election Commission Regulation Number 20 of 2018 to the Supreme Court of the Republic of Indonesia because it is considered contrary to Law Number 7 of 2017 concerning General Elections and other Legislation.

The Supreme Court of the Republic of Indonesia in the Decision 46, P/HUM/2018 with the applicant Jumanto, received the material test related to the Election Commission Regulation Number 20 of 2018 , then with the Judgment of the material test so that exconvicts of corruption can nominate themselves as legislative candidates. This becomes a problem when a controversial situation occurs in the prohibition of ex-convicts as parliamentary candidates, where there are parties who are pros and cons of the ban of exprisoners as legislative candidates have stated their respective arguments, therefore it is essential to review the Interpretation of Judges in the Supreme Court's Decision Number 46 $\mathrm{P} / \mathrm{HUM} / 2018$ in the material test of the Election Commission Regulation Number 20 of 2018.

\section{METHOD}

This study uses a type of normative legal research conducted with approaches to legal norms or substance, legal principles, legal theory, legal arguments, and comparative law. ${ }^{7}$ Material collected from primary, secondary and tertiary legal materials was analyzed qualitatively, arranged systematically and presented descriptively to find out the Interpretation of Judges in the Supreme Court Decision Number 46 P/HUM/2018.

${ }^{7}$ Nawi, Syahruddin. (2014). Penelitian Hukum Normatif Versus Penelitian Hukum Empiris. Makassar: PT. Umitoha Ukhuwah Grafika, p. 6. 


\section{ANALYSIS AND DISCUSSION}

\section{A. Election Perspective in the Indonesian Constitution and Law Number 7 the Year 2017 Regarding Elections}

Democratic countries need norms and practical references and theories from countries whose societies have advanced in democracy. These norms and recommendations must be legitimized as the Constitution of a State in exercising its power. The Unitary State of the Republic of Indonesia has a constitution known as the 1945 Constitution freedom of expression without threat, freedom to access information and freedom of association. ${ }^{8}$ The constitution of the Basic Law is as a grantor and boundary, as well as on how the power of the State must be exercised. ${ }^{9}$

The concept of a modern democratic state, the constitution is a necessity that is not understood as a limitation of the authority of the ruler or king, but the law is recognized as a guideline for the administration of state power to achieve the objectives of the State. The Unitary State of the Republic of Indonesia has set the principles of fair elections in its constitution. To uphold the General Election as a process of government change or rotation of the power of the Unitary State of the Republic of Indonesia has set it in Article $22 \mathrm{E}$ of the Constitution, ${ }^{10}$ and has mandated the General Election Commission as the organizer of the election to ensure and guarantee the process of holding direct, general, free, confidential, honest elections and also guarantee the holding of elections every five years. The election implementation is then regulated in Law Number 7 of 2017 concerning General Elections, which becomes a guideline for KPU as the election organizer. The KPU's authority stated in Article 13 of Law No. 7 of 2017 has explicitly stated, and in Article 14 letter b, the KPU has also expressly stated its obligations. ${ }^{11}$

In addition to treating the Election Participants fairly and equally in the Nominations of Members of the DPR, DPD, Provincial DPRD and Regency/ City DPRD, each candidate must fulfill the requirements as stated in Article 240 paragraph (1) and (2) of Law Number 7 of 2017 Concerning Elections. For legislative candidates who have been sentenced to prison must fulfill the conditions stated in paragraph (1) letter $g .{ }^{12}$

\footnotetext{
8Ubaedillah, A., \& Rozak, Abdul. (2012). Pendidikan Kewarganegaraan (Civic Education): Pancasila Demokrasi, HAM, dan Masyarakat Madani. Jakarta: Kencana Prenada Media Group, p. 81.

${ }^{9} /$ bid., p. 102.

${ }^{10}$ Pasal 22E Undang-Undang Dasar Negara Republik Indonesia Tahun 1945.

${ }^{11}$ Pasal 14 Undang-Undang Republik Indonesia Nomor 7 Tahun 2017 tentang Pemilihan Umum (UU No. 7 Tahun 2017). Lembar Negara Republik Indonesia Tahun 2017 No. 182. Tambahan Lembar Negara No. 6109.

${ }^{12}$ Pasal 240 ayat (1) UU No. 7 Tahun 2017.
} 


\section{B. Review of Judicial Power and Judge Interpretation}

A judge can do judicial interpretation and legal discovery because not all statutory provisions are in a clear form so that there is an opportunity for interpretation of Leemten in hetrechvage and norm. ${ }^{13}$ Judges in making decisions have their interpretations in finding the law, and this is confirmed in Article 5 paragraph (1) of Law Number 48 the Year 2009 concerning Judicial Power.

Every person in expressing an opinion must use an argument that is colloquially called "reason." Likewise, a judge in deciding a case must present a piece of evidence, both related to the subject matter and the branch of the case. These arguments must be formulated and arranged carefully, coherently, systematically using first and correct legal language. Then the legal arguments in the judge's decision are called legal considerations or legal reasoning. Legal reasoning is used in two meanings, namely in the broad and narrow sense, namely in the general sense, the legal argument is related to the psychological process carried out by the Judge, to decide on the case it faces. Legal reasoning study, in a broad sense, involves aspects of psychology and biography. Legal reasoning, in the narrow sense, is related to the argument underlying a decision. This study consists of the study of the logic of a decision and relates to the types of discussions, the relationship between reason and determination, as well as the accuracy of the rights or considerations that support the decision.

There were no Judges or Lawyers, who began to argue from a vacuum situation, ${ }^{14} \mathrm{~A}$ legal argument always starts with positive law. Positive law is not a closed or static state but is an ongoing development. From a positive law provision, jurisprudence will determine new norms. People can reason from the favorable legal requirements of the principles contained in positive law to make new decisions. ${ }^{15}$

Legal arguments, are "reasons in the form of explanatory explanations outlined clearly, in the form of a series of logical statements, to strengthen or reject an opinion, standpoint or idea, relating to legal principles, legal norms and concrete legal rules, as well as the legal system and legal discovery" A meaningful argument, only built on the basis of logic, is a "condition sine qua non" so that a decision can be accepted, that is, if it is based on a logical process, in accordance with a formal logic system which is an absolute requirement in arguing. ${ }^{16}$ Logic, in other terms, is called mantic, and different

${ }^{13}$ Hadjon, Philipus M., \& Djatmiati, Tatiek Sri. (2014). Argumentasi Hukum (Legal Argumentation/Legal Reasoning): Langkah-Langkah Legal Problem Solving dan Penyusunan Legal Opinion. Yogyakarta: UGM Press, p. 24

${ }^{14}$ lbid., p. 17.

${ }^{15}$ Isnantiana, Nur Iftitah. (2017). Legal Reasoning Hakim dalam Pengambilan Putusan Perkara di Pengadilan. Islamadina: Jurnal Pemikiran Islam, Universitas Muhammadiyah Purwokerto, 18(2), p. 50. doi: http://dx.doi. org/10.30595/islamadina.v18i2.1920

${ }^{16} \mathrm{lbid}$., pp. $50-51$. 
opinions state that philosophy is the study of methods and laws used to distinguish valid reasoning from reasoning ${ }^{17}$

The interpretation section is one method of legal discovery that provides a clear explanation of the text of the law so that the scope of the rules can be established in connection with certain events. The interpretation by the judge is an explanation that must lead to an acceptable implementation by the public regarding the rule of law for real events. This interpretation method is a means or tool to find out the meaning of the law. The justification lies in its use to implement practical provisions and not in the interests of the method itself. Therefore it must be assessed with the results obtained. ${ }^{18}$ There are several methods of interpretation that are commonly applied: ${ }^{19}$

1. Grammatical or contextual interpretation, by learning and using sentence relationships.

2. Systematic interpretations, contexts, by studying systems and legal formulations include:

a. Reasoning analogy and reasoning a contraction. The use of a contravention is to ensure that something is not stated by law in reverse. Whereas analogy means the extension of the rule of law.

b. Extensive and Restrictive Interpretation (earlier weakest forms are logically no different).

c. Legal refinement or rechtverfijning or specialization of law.

3. Historical interpretation by learning:

a. Legal history, context, past developments of specific religions such as the Criminal Code, BW, Roman law and so on.

b. The history of the law, the context, the explanations of the legislative process in the development of the law.

4. Teleological interpretation, context, by way of social interaction.

Broadly interpretations can be divided into 2 (two) types, namely literal interpretation and functional interpretation. The literal interpretation uses the sentences of the rules as a handle so that they do not come out of the text (Litera egis). Functional interpretations are also called independent interpretations because they do not fully bind to the sound and content of written rules. Functional interpretations attempt to understand a rule by using other sources that are thought to provide greater clarity. ${ }^{20}$

\footnotetext{
${ }^{17}$ Mundiri. (2006). Logika. Jakarta: PT. Raja Grafindo Persada, p. 2.

${ }^{18}$ Mertokusumo, Sudikno. (2016). Mengenal Hukum: Suatu Pengantar. Yogyakarta: Cahaya Atma Pustaka pp. $211-212$.

${ }^{19}$ Dirdjosisworo, Soedjono. (2012). Pengantar Ilmu Hukum. Jakarta: Rajawali Pers, pp. 156 - 157.

${ }^{20}$ Safaat, Muchamad Ali, Widiarto, Aan Eko, \& Suroso, Fajar Laksono. (2017). Pola Penafsiran Konstitusi dalam Putusan Mahkamah Konstitusi Periode 2003 - 2008 dan 2009 - 2013. Jurnal Konstitusi, Mahkamah Konstitusi RI, 14(2), pp. 234 - 261. doi: https://doi.org/10.31078/jk1421
} 
To understand more fully the related research, it is necessary to know that the interpretation of the law:

1. Interpretation according to the meaning of words or terms (taalkundige interpretatie). The judge must find the meaning of the word law by opening a language dictionary or requesting a linguist's statement. Even if that is not enough, the judge must study the word in sentence structure or its relationship with other regulations. This interpretation is the first step taken or a beginning attempt to interpret. ${ }^{21}$

2. Historical Interpretation How this historical interpretation is made by (i) interpret according to the history of law (rechtshistorische interpretatie), and; (ii) explain the stipulation of a provision (wetshistorische interpretation) historically. Historical understanding is a broad interpretation or includes the preceding description. If the examination according to the history of the determination is done by examining the reports of debate in its formulation, the letters sent are related to the activities of the formulation, etc., while the interpretation according to the history of the law is carried out to investigate the origin of the text of the legal system that was once enacted, including also examining the source of the manuscript from other legal systems that are still in force in other countries.

3. For judges, the meaning of historical interpretation is based on practical needs. In general, what is essential for judges is to know the intentions of the drafted law. Law is dynamic, and the development of legislation follows the evolution of society. Therefore, the meaning that can be given to a word in a positive law text now differs from its purpose when it was determined. Hence also, interpretation according to history is essentially just a guide..$^{22}$ However, the interpretation of history not only examines treatises as stories of the formulation of manuscripts, but also examines the history of social, political, economic, and other social events when the formulation of the manuscript is discussed.

4. Systematic Interpretation Systematic interpretation is interpretation according to the existing system in the formulation of the law itself (systematische interpretative). Systematic interpretation can also occur if one legal text and another legal text, in which both regulate the same thing, are related and compared with each other. If for example what is interpreted is an article of a law, then the same provisions, let alone one principle in other regulations, must be used as a reference. ${ }^{23}$

5. Sociological Interpretation. Every interpretation of the law must end with a sociological explanation so that the judge's decision is made following the real conditions in society. Law is a common symptom, so every regulation has a social

\footnotetext{
${ }^{21}$ Khalid, Afif. (2014). Penafsiran Hukum oleh Hakim dalam Sistem Peradilan di Indonesia. Al 'Adl : Jurnal Hukum, Universitas Islam Kalimantan, 6(11), p. 16. doi: http://dx.doi.org/10.31602/aa.v6i11.196

${ }^{22}$ Ibid.

${ }^{23}$ Ibid., p. 17.
} 
duty that is legal certainty in community, where the social purpose of a provision cannot always be understood from the words formulated. Therefore, the judge must look for it. Sociological interpretation is a guarantee of the seriousness of the judge in making decisions because his decision can realize the law in a real atmosphere in society. ${ }^{24}$

6. Authentic or Official Interpretation (authenteke or officiele interpretative). This authoritative interpretation is following the understanding expressed by the legislators in the law itself. ${ }^{25}$ For example, the meaning of the word described in the article or in the explanation. If you want to know what is meant in an article, then the first step is to see the explanation of that article. Therefore, the explanation of the law is always published separately, namely in the Supplement to the State Gazette, while the text of the law in the Official Gazette. On the other hand hermeneutics is used as a method of interpretation that was originally a method of interpretation of the text, but in its development Actually hermeutics is not only a method of interpretation of the text and delve into its literal content, but more than that hermeneutics tries to explore meaning by considering the horizon/horizon that surrounds the text. The horizon in question is the text horizon, author horizon and reader horizon. ${ }^{26}$ Noting these three horizons, an interpretation or understanding becomes an activity of reconstruction and reproduction of the meaning of a text, besides tracking how a version was born by the author and what content enters into it. In addition, an interpreter always tries to regenerate the meaning following the situation and condition when the text is read or understood. Thus, hermeunitika, as a method of interpretation, must always pay attention to three main components, namely writing, context, and contextualization efforts. ${ }^{27}$

The issue of what methods are used by judges in handling a concrete case, the legislators do not give priority to any of the methods in legal discovery. This means that the judge is given the freedom to choose what method is most suitable for handling the case at hand. The choice of legal discovery method is the judge's authority. The choice of one method by the judge is based on what method is most convincing and the results are satisfactory in handling a case..$^{28}$

Progressive law is a concept of how to judge not only one but various ways. To make a clear description of progressive law, it is confronted with a positive-legalistic method of punishment, so that in the final method of punishment the law is implementing

${ }^{26}$ Muwahid. (2017). Metode Penemuan Hukum (Rechtsvinding) oleh Hakim dalam Upaya Mewujudkan Hukum yang Responsif. Al-Hukama': The Indonesian Journal of Islamic Family Law, Universitas Islam Negeri Sunan Ampel, 7(1), pp. 240 - 241. doi: https://doi.org/10.15642/alhukama.2017.7.1.224-248

${ }^{27}$ Ibid., p. 241.

${ }^{28}$ /bid.
} 
the law. This method of law is based solely on the law (alles binnen de kader van de wet) or spelling the law. Here people do not think far except reading the text and its application, it looks like this way of punishment is like drawing a straight line between two points. One point is (article) the law and the other point is the facts that occur. Everything runs linearly, so that the method of law is like an automatic machine, and is referred to as "hanteren van logicalche figuren" and as "a book of mathematics."29

Progressive punishment can also be interpreted as testing the limits of legal ability. If it is said that carrying out the law is to create justice in society, then the code is an effort to realize that justice. Text law alone does not automatically create sentence. Therefore people distinguish between truth according to the text (forma/ legal justice) and actual justice (substantial justice). Justice is in the law, but it still needs to be found (het recht is in de wet, maar het moet nog gevonden warden). Thus the code is not the same as applying the law, but rather an attempt to bring justice stored in it, so that is the meaning of testing the limits of legal ability. ${ }^{30}$

Judges are not legislators because their job is to mediate or examine and decide. The task of making the law is in the realm of the legislature, and however, in the end, the judge determines what the law wants. The judge must decide based on the law, but in fact, he does not only spell the text of the law but also decides what is stored in the book. Deciding the law is not done by reading the book (textual reading) but digging the moral behind it (good reading). Thus the judge actually also makes the law at a higher level. ${ }^{31}$

Here the judge does not perform an independent function in applying the law to concrete legal events. Judges are merely mouthpieces of laws that cannot change or add to laws. This classic view maintained by Montesquieu and Kant is based on Montesquieu's basic mind that the legislators are the only source of positive law. For the sake of legal certainty, the legal unity and freedom of its citizens who are threatened by arbitrary actions of the judge, the judge must submit to the legislators. This view suggests the judiciary is nothing but a shaper of syllogism. The law is a major premise, a concrete event is a minor premise, while the judge's decision is a conclusion or conclusion. A logical conclusion will not cover more than what is in the premises. Likewise, a judge's decision will not contain or include more than what is contained in the law relating to a concrete event. This is a typologically logical view. ${ }^{32}$

\footnotetext{
${ }^{29}$ Rahardjo, Satjipto. (2011). Memahami Hukum: Dari Konstruksi sampai Implementasi. Jakarta: PT. Raja Grafindo Persada, p. 3.

${ }^{30} \mathrm{lbid}$., p. 4.

${ }^{31} \mathrm{lbid}$.

${ }^{32}$ Mertokusumo, Sudikno. (2016). Loc. Cit.
} 


\section{Decision of the Supreme Court Number 46 P/HUM/2018}

The decision of the Supreme Court Number $46 \mathrm{P} / \mathrm{HUM} / 2018$ has granted the material test to the General Election Commission Regulation (PKPU) Number 20 of 2018, has canceled Article 4 paragraph (3), Article 11 paragraph (1) letter d and Appendix Model B.3 Election Commission Regulation Number 20 Year 2018.

\begin{tabular}{l|l|l}
\hline Ref & Article PKPU No. 20 Year 2018 & $\begin{array}{l}\text { Supreme Court Judgment No. 46 P/ } \\
\text { HUM/2018 }\end{array}$ \\
\hline \hline $\mathbf{1 .}$ & $\begin{array}{l}\text { Article 4 paragraph (3) "In the selection } \\
\text { of prospective candidates in a } \\
\text { democratic and open manner as referred } \\
\text { to in paragraph (2) does not include } \\
\text { former convicted drug dealers, sexual } \\
\text { crimes against children, and corruption" }\end{array}$ & $\begin{array}{l}\text { Article 4 paragraph (3) PKPU No. 20 of } \\
2018 \text { has no binding legal force and is } \\
\text { not generally valid, as long as the phrase } \\
\text { "ex-convicted of corruption" contradicts } \\
\text { a higher regulation, namely Law Number } \\
7 \text { of 2017 concerning General Election } \\
\text { in conjunction with Law Number 12 of } \\
\text { 2011 concerning Formation of Laws and } \\
\text { Regulations - Invitation. }\end{array}$ \\
\hline $\mathbf{2 .}$ & $\begin{array}{l}\text { Article 11 paragraph (1) letter d } \\
\text { "Requirements for nominating candidates } \\
\text { as referred to in article 10 paragraph (1) } \\
\text { are in the form of:... (d) an integrity pact } \\
\text { signed by the leadership of a Political } \\
\text { Party in accordance with its level using } \\
\text { the form of Model B.3". }\end{array}$ & $\begin{array}{l}\text { Article 11 paragraph (1) PKPU No. 20 of } \\
\text { 2018 does not have binding legal force } \\
\text { and does not generally apply as a phrase } \\
\text { in Article 4 paragraph (3) PKPU No. 20 } \\
\text { of 2018. }\end{array}$ \\
\hline 3. & Appendix Model B.3 & $\begin{array}{l}\text { Has no binding legal force and is not } \\
\text { generally applicable }\end{array}$ \\
\hline
\end{tabular}

\section{Table Amar Decision of the Supreme Court Number 46 P/HUM/2018}

Decision of the Supreme Court Number 46 P/HUM/2018 there are a number of considerations in deciding upon the judicial review. As the contents of the copy as follows:

Whereas the right to elect and be elected as a member of the Legislature is a basic right in the political field guaranteed by the Constitution, namely Article 28 of the 1945 Constitution of the Republic of Indonesia. The Supreme Court also sees that Article 4 paragraph (3) of the Election Commission Regulation Number 20 of 2018 is in conflict with the provisions of Article 240 paragraph (1) letter $g$ of Law Number 7 of 2017 concerning General Elections, which states that candidates for DPR, Provincial DPRD and Regency/City DPRD are Indonesian citizens and must meet the requirements $:^{33} \ldots \mathrm{g}$ ) "have never been imprisoned based on a court decision that has obtained permanent legal force for committing a crime threatened with imprisonment of 5 (five) years or more, unless openly and honestly telling the public that the person concerned is a former convict".

${ }^{33}$ Putusan Mahkamah Agung Republik Indonesia Nomor 46 P/HUM/2013 tentang Permohonan Keberatan Hak Uji Materiil atas Pasal 4 ayat (3), Pasal 11 Ayat (1) huruf d, dan Lampiran Model B.3 Pakta Integritas Pengajuan Bakal Calon Anggota DPR/DPRD Provinsi/DPRD Kabupaten/Kota, Peraturan Komisi Pemilihan Umum Nomor 20 Tahun 2018 tentang Pencalonan Anggota Dewan Perwakilan Rakyat, Dewan Perwakilan Rakyat Daerah Provinsi dan Dewan Perwakilan Rakyat Daerah Kabupaten/Kota. 
Whereas in the provisions of Article 240 paragraph (1) letter $g$ there is no norm that prohibits former corruption convicts from nominating themselves as candidates for DPR and DPRD. The Supreme Court considers Article 4 paragraph (3), Article 11 paragraph (1) letter $d$ and the Model Attachment B.3 Regulation of the Election Commission Number 20 of 2018 in principle has limited the political rights of someone who will run as a prospective legislative candidate in the general election.

The considerations of the Supreme Court in terms of the formation of legislation containing Article 4 paragraph (3), Article 11 paragraph (1) letter g and Appendix Model B. 3 of the Election Commission Regulation Number 20 Year 2018 are not in line, conflict or do not meet the principles Formation of good statutory regulations as explained in Article 12 letter d of Law Number 12 of 2011, namely "the regulations under the law contain material to carry out the law as it should". However, the material in Article 4 paragraph (3), Article 11 paragraph (1) letter $g$ and Appendix to Model B.3 of the Election Commission Regulation Number 20 Year 2018 which regulates a person's political rights and contains a prohibition for former corruption convicts to run for people's representatives is regulations which have never been ordered by the laws above, in this case Law Number 7 of 2017 concerning General Election in conjunction with Law Number 12 of 2011 concerning Formation of Laws and Regulations. The judge saw an Election Commission action that made provisions that were not ordered by law.

Decision of the Supreme Court Number 46 P/HUM/2018, the judge mentioned several considerations as the basis of interpretation such as Article 28 of the 1945 Constitution, Law Number 12 of 2005 concerning Ratification of the International Covenant on Civil and Political Rights (International Covenant on Rights Civil and Politics), Article 43 paragraph (1) and Article 73 of Law Number 39 concerning Human Rights, Article 18 paragraph (1) letter d of Law Number 31 of 1999 Concerning Eradication of Corruption in conjunction with Article 35 paragraph (1) The Criminal Code (KUHP) which regulates the revocation of political rights (the right to choose and vote).

Based on the judges' considerations above in adjudicating and adjudicating cases mentioning Article 4 paragraph (3), Article 11 paragraph (1) letter $g$ and Appendix Model B.3 of the Election Commission Regulation Number 20 Year 2018 is contrary to Law Number 7 Year 2017 concerning General Election in conjunction with Law Number 12 of 2011 concerning the Formation of Regulations and Regulations in its ruling so that the two laws become the main basis for the test in interpreting but also other considerations are inseparable parts because they also have a relationship with the judge's ruling.

Decision of the Supreme Court Number $46 \mathrm{P} / \mathrm{HUM} / 2018$ when viewed from the method of legal discovery by a judge making legal discoveries based on the law, interpretation is made of the norms in the law as a guide, the text in the law becomes 
the main reference by the judge in deciding the case. The first time taken by the judge in the beginning of the interpretation of the judge must learn the word in the wording of the sentence or its relationship with other regulations, and this is the first way that must be done by the judge. Therefore the Supreme Court Decision Number 46 P/HUM/2018 must be respected because it has been through the method of interpretation that is in accordance with the principles and principles in applying its power in finding and creating law.

\section{CONCLUSION}

Decision of the Supreme Court Number $46 \mathrm{P} / \mathrm{HUM} / 2018$ which adjudicates that Article 4 paragraph (3), Article 11 paragraph (1) letter $g$ and Appendix Model B.3 Election Commission Regulation Number 20 Year 2018 is contrary to Law Number 7 Year 2017 concerning General Election in conjunction with Law Number 12 of 2011 concerning Formation of Regulations and Regulations Judges' considerations are based on the interpretation of the test object test stones namely the sentences in the text of Law Number 7 of 2017 concerning Elections and Law Number 12 of 2011 concerning the Formation of Laws and Regulations as a guide so that the interpretation of judges is based on exploring the meaning contained in written norm text statements by studying the text in sentence structure or its relationship to other regulations.

\section{REFERENCE}

Asshiddiqie, Jimly. (2009). Menuju Negara Hukum yang Demokratis. Jakarta: PT. Bhuana IImu Populer.

Dirdjosisworo, Soedjono. (2012). Pengantar IImu Hukum. Jakarta: Rajawali Pers.

Hadi, Syafiul, \& Wijanarko, Tulus. (2019, 29 Januari). Hari Ini, KPU Umumkan Caleg yang Mantan Narapidana. Tempo.Co. Retrieved from https://pemilu.tempo.co/ read/1169965/hari-ini-kpu-umumkan-caleg-yang-mantan-narapidana

Hadjon, Philipus M., \& Djatmiati, Tatiek Sri. (2014). Argumentasi Hukum (Legal Argumentation/Legal Reasoning): Langkah-Langkah Legal Problem Solving dan Penyusunan Legal Opinion. Yogyakarta: UGM Press.

Isnantiana, Nur Iftitah. (2017). Legal Reasoning Hakim dalam Pengambilan Putusan Perkara di Pengadilan. Islamadina: Jurnal Pemikiran Islam, Universitas Muhammadiyah Purwokerto, 18(2), 41 - 56. doi: http://dx.doi.org/10.30595/islamadina.v18i2.1920

Junaidi, Veri. (2010). Pelanggaran Sistematis, Terstruktur dan Masif: Suatu Sebab Pembatalan Kehendak Rakyat dalam Pemilihan Kepala Daerah Tahun 2010. Jurnal Konstitusi, Mahkamah Konstitusi RI, 7(5), 41 - 72. doi: https://doi.org/10.31078/jk\%25x 
Khalid, Afif. (2014). Penafsiran Hukum oleh Hakim dalam Sistem Peradilan di Indonesia. Al 'Adl : Jurnal Hukum, Universitas Islam Kalimantan, 6(11), 9 - 36. doi: http:// dx.doi.org/10.31602/aa.v6i11.196

Mamonto, Moch. Andry Wikra Wardhana. (2019). Legal Politics of Simplifying Political Parties in Indonesia (Case Study of 2004 - 2014 Election). Substantive Justice International Journal of Law, Universitas Muslim Indonesia, 2(1), 1 - 20. doi: http:// dx.doi.org/10.33096/substantivejustice.v2i1.25

Mertokusumo, Sudikno. (2016). Mengenal Hukum: Suatu Pengantar. Yogyakarta: Cahaya Atma Pustaka.

Mundiri. (2006). Logika. Jakarta: PT. Raja Grafindo Persada.

Muwahid. (2017). Metode Penemuan Hukum (Rechtsvinding) oleh Hakim dalam Upaya Mewujudkan Hukum yang Responsif. Al-Hukama': The Indonesian Journal of Islamic Family Law, Universitas Islam Negeri Sunan Ampel, 7(1), 224 - 248. doi: https://doi.org/10.15642/alhukama.2017.7.1.224-248

Nawi, Syahruddin. (2014). Penelitian Hukum Normatif Versus Penelitian Hukum Empiris. Makassar: PT. Umitoha Ukhuwah Grafika.

Peraturan Komisi Pemilihan Umum Republik Indonesia Nomor 20 Tahun 2018 tentang Dewan Perwakilan Rakyat Daerah Provinsi Pencalonan Anggota Dewan Perwakilan Rakyat, dan Dewan Perwakilan Rakyat Daerah Kabupaten/Kota. Berita Negara Republik Indonesia No. 834.

Putusan Mahkamah Agung Republik Indonesia Nomor 46 P/HUM/2013 tentang Permohonan Keberatan Hak Uji Materiil atas Pasal 4 ayat (3), Pasal 11 Ayat (1) huruf d, dan Lampiran Model B.3 Pakta Integritas Pengajuan Bakal Calon Anggota DPR/DPRD Provinsi/DPRD Kabupaten/Kota, Peraturan Komisi Pemilihan Umum Nomor 20 Tahun 2018 tentang Pencalonan Anggota Dewan Perwakilan Rakyat, Dewan Perwakilan Rakyat Daerah Provinsi dan Dewan Perwakilan Rakyat Daerah Kabupaten/Kota.

Putusan Mahkamah Konstitusi Republik Indonesia Nomor 14/PUU-XI/2013 tentang Pengujian Undang-Undang Nomor 42 Tahun 2008 tentang Pemilihan Umum Presiden dan Wakil Presiden.

Rahardjo, Satjipto. (2011). Memahami Hukum: Dari Konstruksi sampai Implementasi. Jakarta: PT. Raja Grafindo Persada.

Respationo, H. M. Soerya. (2013). Pemilihan Kepala Daerah dalam Demokrasi Electoral. Masalah-Masalah Hukum, Universitas Diponegoro, 42(3), 356 - 361. doi: https:// doi.org/10.14710/mmh.42.3.2013.356-361 
Volume 2, Issue 2, December $2019: 147-160$

Safaat, Muchamad Ali, Widiarto, Aan Eko, \& Suroso, Fajar Laksono. (2017). Pola Penafsiran Konstitusi dalam Putusan Mahkamah Konstitusi Periode 2003 - 2008 dan 2009 - 2013. Jurnal Konstitusi, Mahkamah Konstitusi RI, 14(2), 234 - 261. doi: https://doi.org/10.31078/jk1421

Smith, C. E. (2009). De Betekenis van de Prototypische Gevallen voor de Rechtsvinding: Taalkundige Interpretatie. Trema Tijdschrift voor de Rechterlijke Macht, Nederlandse Vereniging voor Rechtspraak, 8, 336 - 341.

Ubaedillah, A., \& Rozak, Abdul. (2012). Pendidikan Kewarganegaraan (Civic Education): Pancasila, Demokrasi, HAM, dan Masyarakat Madani. Jakarta: Kencana Prenada Media Group.

Undang-Undang Dasar Negara Republik Indonesia Tahun 1945.

Undang-Undang Republik Indonesia Nomor 42 Tahun 2008 tentang Pemilihan Umum Presiden dan Wakil Presiden. Lembar Negara Republik Indonesia Tahun 2008 No. 176. Tambahan Lembar Negara No. 4924.

Undang-Undang Republik Indonesia Nomor 12 Tahun 2011 tentang Pembentukan Peraturan Perundang-Undangan. Lembar Negara Republik Indonesia Tahun 2011 No. 5234.

Undang-Undang Republik Indonesia Nomor 7 Tahun 2017 tentang Pemilihan Umum. Lembar Negara Republik Indonesia Tahun 2017 No. 182. Tambahan Lembar Negara No. 6109. 